\title{
Penggunaan Acute IIIness Observation Scale [AIOS] sebagai Prediktor Infeksi Serius pada Anak 3-36 Bulan dengan Demam
}

\author{
A.A.A. Putu Indah Pratiwi, Dimple V. Nagrani, Yusuf Balfast, Alan R. Tumbelaka, Waldi \\ Nurhamzah \\ Departemen Ilmu Kesehatan Anak, Fakultas Kedokteran Universitas Indonesia - Rumah Sakit Cipto \\ Mangunkusumo
}

Latar belakang. Anak dengan infeksi bakterial serius seringkali tidak menunjukkan gejala khas sehingga sulit dibedakan dengan infeksi ringan. Instrumen tunggal untuk mendiagnosis demam belum ditemukan namun beberapa skala sudah digunakan secara luas untuk memprediksi infeksi bakterial serius pada anak. Acute illness observation scale (AIOS) adalah salah satu skala observasi yang sering digunakan. Skala AIOS sederhana, mudah, dan tidak invasif. Penelitian sebelumnya menunjukkan AIOS memiliki nilai diagnostik yang baik.

Tujuan. Mengetahui nilai diagnostik AIOS dalam memprediksi penyakit infeksi bakterial serius pada anak usia 3-36 bulan dengan demam.

Metode. Uji diagnostik dilakukan di Departemen Ilmu Kesehatan Anak FKUI/RSCM, RSUP Fatmawati, dan RSAB Harapan Kita, pada bulan Maret sampai dengan Mei 2010. Subjek adalah anak usia 3-36 bulan dengan demam $\leq 7$ hari.

Hasil. Terdapat 270 subjek yang diikutsertakan dalam penelitian dan 256 subjek di antaranya dapat dianalisis. Sebagian besar subjek berusia 3-12 bulan. Infeksi serius ditemukan pada 62 subjek dengan diagnosis pneumonia sebagai diagnosis tersering. Skor AIOS >10 memiliki sensitivitas, spesifisitas, nilai duga positif (NDP), nilai duga negatif (NDN), rasio kemungkinan positif (RKP), dan rasio kemungkinan negatif (RKN) berturut-turut 58,06\%, 94,33\%,76,6\%; 87,56\%; 10,24; dan 0,44 untuk memprediksi infeksi serius pada anak 3-36 bulan dengan demam. Ditemukan titik potong baru yaitu skor AIOS >8 dengan sensitivitas, spesifisitas, NDP, NDN, RKP, dan RKN 69,35\%; 90,2\%; 69,35\%; 90,2\%; 7,08; dan 0,34.

Kesimpulan. Skor AIOS >10 dapat digunakan untuk memprediksi infeksi serius pada anak 3-36 bulan. Ditemukan nilai titik potong baru, yaitu skor AIOS $>8$ yang memiliki nilai diagnostik lebih baik dari AIOS $>10$ namun diperlukan penelitian lebih lanjut dengan menggunakan titik potong tersebut.(Sari Pediatri 2010;12(2):116-23).

Kata kunci: acute illness observation scale, serious bacterial infection, fever without source

\footnotetext{
Alamat korespondensi:

Dr. Alan R. Tumbelaka, SpA(K). Divisi Infeksi Tropis. Departemen Ilmu Kesehatan Anak FKUI-RSCM. JI Salemba no. 6. Jakarta 10430. Telepon/ faksimili:021-3914126 Email:alanrt@yahoo.com
} 
Ceorang anak pada tiga tahun pertama kehidupannya seringkali mengalami beberapa episode infeksi akut yang sering disertai demam. Demam sampai saat ini masih menjadi salah satu alasan utama orangtua membawa anaknya berobat ke dokter. Demam pada sebagian besar kasus merupakan tanda infeksi ringan, seperti infeksi virus, namun ternyata dapat juga menjadi petanda infeksi serius, misalnya bakteremia, infeksi saluran kemih, pneumonia, gastroenteritis bakterialis, meningitis, infeksi tulang dan sendi, serta infeksi jaringan lunak. Infeksi bakterial serius dilaporkan terjadi sebanyak 6\%-15\% pada anak demam usia 3-36 bulan. ${ }^{1,2}$

Anak dengan infeksi bakterial serius seringkali tidak menunjukkan gejala klinis yang khas sehingga sering sulit dibedakan dengan anak lain dengan infeksi ringan. ${ }^{3,4} \mathrm{Hal}$ itu mengakibatkan tata laksana infeksi sebagai penyebab demam akut menjadi berlebihan (misalnya penggunaan antibiotik dan indikasi rawat yang tidak tepat) atau sebaliknya, infeksi berat tidak terdiagnosis (underdiagnosed) sehingga tata laksana yang tepat terlambat diberikan. Hal tersebut membuat para klinisi merasa perlu alat diagnostik yang dapat membantu mendiagnosis demam pada anak agar tata laksana demam lebih terarah. Beberapa instrumen dibuat untuk membantu klinisi untuk mendeteksi penyakit bakterial serius namun sebenarnya tidak ada satupun uji diagnostik yang cukup sensitif atau spesifik untuk menduga infeksi bakterial berat. Pendekatan rasional tetap harus digunakan dalam

Tabel 1. Acute illness observation scales (AIOS)

\begin{tabular}{|c|c|c|c|}
\hline Hal yang diobservasi & Normal & Gangguan sedang & Gangguan parah \\
\hline Kualitas tangisan & $\begin{array}{l}\text { - Kuat dengan nada normal } \\
\text { ATAU } \\
\text { - Merasa nyaman dan tidak } \\
\text { menangis }\end{array}$ & $\begin{array}{l}\text { - } \text { Merengek-rengek } \\
\text { ATAU } \\
\text { - Terisak-isak }\end{array}$ & $\begin{array}{l}\text { - Lemah ATAU } \\
\text { - Mengerang } \\
\text { - Nada tinggi }\end{array}$ \\
\hline $\begin{array}{l}\text { Reaksi terhadap stimulasi } \\
\text { orang tua (pengaruh pada } \\
\text { tangisan ketika diangkat, } \\
\text { ditepuk-tepuk pada } \\
\text { punggung, ditimang- } \\
\text { timang di pangkuan, } \\
\text { atau digendong) }\end{array}$ & $\begin{array}{l}\text { - Menangis sebentar lalu } \\
\text { berhenti } \\
\text { - Merasa nyaman dan tidak } \\
\text { menangis }\end{array}$ & $\begin{array}{l}\text { - Menangis sebentar- } \\
\text { sebentar }\end{array}$ & $\begin{array}{l}\text { - Menangis terus } \\
\text { menerus ATAU } \\
\text { - Hampir tidak memberi } \\
\text { reaksi }\end{array}$ \\
\hline $\begin{array}{l}\text { Variasi dalam keadaan } \\
\text { (mulai dari bangun } \\
\text { sampai tidur atau } \\
\text { tidur sampai bangun) }\end{array}$ & $\begin{array}{l}\text { - Bila sedang bangun akan } \\
\text { tetap bangun ATAU } \\
\text { - Bila sedang tidur dan } \\
\text { distimulasi akan mudah } \\
\text { terbangun }\end{array}$ & $\begin{array}{l}\text { Mata tertutup sebentar, } \\
\text { kemudian terbangun } \\
\text { ATAU } \\
\text { Bangun dengan } \\
\text { stimulasi yang lama }\end{array}$ & $\begin{array}{l}\text { - Tidak dapat bangun } \\
\text { ATAU } \\
\text { - Tertidur }\end{array}$ \\
\hline Warna & - Merah muda (pink) & $\begin{array}{l}\text { - Telapak tangan dan } \\
\text { kaki pucat ATAU } \\
\text { - Akrosianosis (telapak } \\
\text { tangan dan kaki biru) }\end{array}$ & $\begin{array}{l}\text { - } \text { Pucat ATAU } \\
\text { - } \text { Biru ATAU } \\
\text { - Tidak bersinar (kelabu) } \\
\text { - ATAU } \\
\text { - Berbercak-bercak }\end{array}$ \\
\hline $\begin{array}{l}\text { Hidrasi (kelembaban } \\
\text { kulit, mata dan mulut) }\end{array}$ & $\begin{array}{l}\text { - Kulit normal SERTA } \\
\text { mata dan mulut basah }\end{array}$ & $\begin{array}{l}\text { Kulit dan mata normal } \\
\text { DAN mulut agak } \\
\text { kering }\end{array}$ & $\begin{array}{l}\text { Kulit tidak kembali } \\
\text { bila ditekan DAN mata } \\
\text { kemungkinan cekung } \\
\text { DAN mata serta mulut } \\
\text { kering }\end{array}$ \\
\hline $\begin{array}{l}\text { Reaksi pada kontak sosial } \\
\text { (dipegang, disentuh, } \\
\text { diajak berbicara, } \\
\text { ditenangkan) }\end{array}$ & $\begin{array}{l}\text { - } \text { Tersenyum ATAU } \\
\text { - Memberikan reaksi (2 } \\
\text { bulan atau kurang) }\end{array}$ & $\begin{array}{l}\text { - Tersenyum sebentar } \\
\text { - ATAU } \\
\text { Memberikan reaksi } \\
\text { sebentar ( } 2 \text { bulan atau } \\
\text { kurang) }\end{array}$ & $\begin{array}{l}\text { - Tidak tersenyum, wajah } \\
\text { gelisah ATAU } \\
\text { - Tanpa cahaya, tanpa } \\
\text { ekspresi ATAU } \\
\text { - Tidak memberikan } \\
\text { reaksi ( } 2 \text { bulan atau } \\
\text { kurang) }\end{array}$ \\
\hline
\end{tabular}


A.A.A. Putu Indah Pratiwi dkk: Penggunaan acute illness observation scale (AIOS) sebagai prediktor infeksi serius pada anak 3-36 bulan dengan demam

mempertimbangkan tata laksana demam pada anak. Salah satu instrumen yang sering digunakan adalah skala observasi yang dibuat oleh McCarthy dkk, yaitu Yale Observation Scales (YOS) atau acute illness observation scales (AIOS). Skala ini terdiri dari 6 aspek pengamatan yang dapat diterapkan saat pemeriksaan di ruang praktek. Instrumen AIOS sederhana dan tidak invasif, bahkan dilaporkan dapat digunakan oleh orangtua. ${ }^{5,6}$ Literatur terakhir melaporkan bahwa sensitivitas dan spesifisitas instrumen AIOS cukup baik dalam memprediksi penyakit bakterial serius berturutturut $87,9 \%$ dan $83,8 \%{ }^{7}$

Di beberapa negara, AIOS sudah digunakan secara luas dalam algoritma penanganan demam pada anak. Skala AIOS sederhana sehingga relatif mudah digunakan, tidak memerlukan pemeriksaan invasif, dan tidak memerlukan waktu lama untuk mengerjakannya. Penggunaan AIOS sebagai alat skrining terbukti dapat menghemat biaya kesehatan dengan mengurangi pemeriksaan dan pemberian terapi yang tidak perlu. ${ }^{8}$

Di Indonesia belum pernah diteliti mengenai penggunaan AIOS pada kelompok usia 3-36 bulan dengan demam. Penelitian sebelumnya dilakukan Idris ${ }^{9}$ di Poliklinik Pediatri Umum Rumah Sakit Cipto Mangunkusumo (RSCM) pada 35 subjek usia 5-180 bulan menunjukkan nilai diagnostik yang cukup baik dengan sensitivitas dan spesifisitas AIOS $79,2 \%$ dan $62,5 \%$ dengan rasio kemungkinan positif 2. Hasil penelitian tersebut menunjukkan bahwa instrumen AIOS cukup baik digunakan sebagai alat penyaring penyakit serius pada anak dengan demam. Penelitian pendahuluan tersebut menyarankan dilakukan studi dengan subyek yang lebih banyak pada kelompok umur tertentu untuk melakukan validasi nilai diagnostik instrumen AIOS dengan lebih baik.

\section{Metode}

Penelitian prospektif dilakukan di tiga rumah sakit rujukan di Jakarta, yaitu RS Cipto Mangunkusumo, RSUP Fatmawati, dan RSAB Harapan Kita pada bulan Maret sampai dengan Mei 2010. Pemilihan subjek penelitian dilakukan di Poliklinik, Unit Gawat Darurat, dan bangsal rawat inap. Subjek penelitian adalah anak usia 3-36 bulan dengan demam $<7$ hari. Demam apabila didapatkan suhu tubuh $\geq 37,5^{\circ} \mathrm{C}$ yang diukur dengan termometer air raksa di aksila selama 5 menit. Subjek tidak diikutsertakan apabila menderita palsi serebral, defisiensi imun, dan riwayat penyakit autoimun atau keganasan. Pemilihan subjek dilakukan dengan metode convenient sampling.

Formulir penelitian diisi oleh semua anak yang memenuhi kriteria penelitian. Pada kunjungan awal, sebelum dilakukan anamnesis dan pemeriksaan fisis, pasien yang memenuhi kriteria inklusi diobservasi dengan instrumen AIOS oleh satu orang dokter pemeriksa. Instrumen AIOS telah dialih bahasa oleh penterjemah yang telah disumpah. Kuesioner menilai enam aspek, yaitu kualitas tangisan, reaksi terhadap stimulasi orangtua, variasi dalam keadaan, warna, hidrasi, dan respon pada kontak sosial, Nilai masingmasing aspek 1 jika normal, 3 jika terdapat gangguan sedang, dan 5 jika terdapat gangguan yang parah.

Penentuan skor AIOS dilakukan saat anak duduk di pangkuan orangtua atau pengasuh. Aspek penilaian yang tidak atau membutuhkan interaksi minimal, seperti warna dan hidrasi, dinilai terlebih dahulu. Kemudian orangtua/pengasuh diminta untuk menenangkan atau membuat nyaman anak dengan menggendong, bercakap-cakap, atau memberikan ASI/botol. Setelah anak tenang, dilakukan penilaian terhadap aspek-aspek yang memerlukan stimulasi, yaitu kualitas tangisan, reaksi terhadap stimulasi orangtua, dan respon pada kontak sosial. Berdasarkan observasi tersebut, ditentukan skor AIOS dengan rentang 6 sampai dengan 30. Pasien dengan skor total 10 atau lebih diprediksi mengalami penyakit serius. Peneliti tidak mengkomunikasikan hasil skala dengan dokter pemeriksa sampai dokter pemeriksa memutuskan diagnosis dan tata laksana pasien. Diagnosis akhir (penyakit serius atau tidak serius) ditentukan melalui evaluasi saat kunjungan lanjutan, penilaian di bangsal jika pasien dirawat, atau pemantauan per telepon (dilakukan pada 7 hari pasca kunjungan) pada pasien yang tidak melakukan kunjungan ulang.

Penilaian penyakit bakterial serius apabila ditemukan sedikitnya salah satu dari hal berikut. (1) Ditemukan bakteri patogen pada biakan darah, likuor serebrospinal, urin, cairan sendi, atau aspirat jaringan; (2) Terdapat kelainan elektrolit, foto toraks, gas darah, atau analisis likuor serebrospinal dan/atau bila pasien didiagnosis sebagai meningitis, pneumonia, bakteremia, infeksi jaringan lunak, diare akibat bakteri, dan infeksi saluran kemih atau infeksi tulang. Penyakit infeksi tidak serius antara lain mencakup infeksi yang 
A.A.A. Putu Indah Pratiwi dkk: Penggunaan acute illness observation scale (AIOS) sebagai prediktor infeksi serius pada anak 3-36 bulan dengan demam

diduga akibat virus (presumed viral infection), termasuk rinotonsilofaringitis akut karena virus, common cold, infeksi saluran pernapasan akut (ISPA), eksantema akut, diare akibat virus, dan semua gejala demam yang sembuh dalam waktu kurang dari 7 hari. Persetujuan etik diperoleh dari Komite Etik Fakultas Kedokteran Universitas Indonesia.

Data kemudian diolah dengan piranti lunak SPSS 17.0, skor AIOS dihitung nilai reratanya. Skor AIOS dihitung sensitivitas, spesifisitas, nilai duga positif (NDP), nilai duga negatif (NDN), rasio kemungkinan positif (RKP), dan rasio kemungkinan negatif (RKN) untuk mengetahui nilai diagnostik AIOS memprediksi infeksi bakterial serius pada anak 3-36 bulan. Seluruh data skor AIOS kemudian dimasukkan ke dalam kurva receiver operating characteristic (ROC) untuk mencari nilai titik potong AIOS yang paling baik. Masingmasing nilai titik potong kemudian akan dicari nilai diagnostiknya.

Kesahihan AIOS diuji dengan menghitung kesesuaian interobserver antara 3 pengamat dengan menghitung kappa. Nilai kappa 0-0,2: tingkat kesesuaian sangat rendah; 0,21-0,4: tingkat kesesuaian rendah; 0,41-0,6: tingkat kesesuaian sedang; 0,61-0,8; tingkat kesesuaian kuat; 0,81-1: tingkat kesesuaian sangat kuat.

\section{Hasil}

Selama kurun waktu penelitian diperoleh 273 subjek. Seratus dua puluh enam subjek dari RSCM (MaretMei 2010), RS Fatmawati (April-Mei 2010) 100 subjek, dan RSAB Harapan Kita (Mei 2010) 47 subjek. Lima subjek tidak diikutsertakan karena pada 3 subjek demam tidak terdokumentasi secara objektif dan 2 subjek lain menderita tersangka leukemia akut dan infeksi HIV. Dua belas subjek (4,39\%) tidak dapat dihubungi setelah rawat jalan sehingga tidak diikutkan dalam analisis berikutnya; analisis kemudian dilakukan pada 256 subjek $(94,1 \%)$.

Laki-laki lebih banyak daripada perempuan dengan rasio $1,7: 1$, tingkat pendidikan kedua orangtua pasien sebagian besar adalah pendidikan menengah, dan sebagian besar 149 subjek $(58,2 \%)$ mempunyai gizi kurang. Median usia subjek adalah 12 bulan (3-36 bulan), dan kelompok usia terbanyak 3-12 bulan (136 subjek, 53,1\%). Median lama demam sebelum subjek dibawa ke dokter adalah 3
(1-7) hari. Keluhan tersering yang menyertai demam adalah batuk pilek dan diare yang ditemukan pada masing-masing 84 subjek $(32,8 \%)$ dan 77 subjek $(30,1 \%)$. Median suhu adalah $38,5(37,5-41,6)^{\circ} \mathrm{C}$. Hasil pemeriksaan fisis dan laboratorium diperoleh dari data rekam medis, sesuai indikasi dari dokter anak yang memeriksa di masing-masing rumah sakit. Pemeriksaan penunjang yang dianalisis dalam penelitian ini adalah pemeriksaan yang berkaitan dengan penyakit infeksi (Tabel 2).

Tabel 2. Karakteristik klinis dan laboratoris subjek penelitian

\begin{tabular}{lc}
\hline Karakteristik & $\begin{array}{c}\text { Rerata (SB)\#/ } \\
\text { Median (rentang)* }\end{array}$ \\
\hline Suhu, ${ }^{\circ} \mathrm{C}$ & $38,4(37,1-41,6)^{*}$ \\
Frekuensi nadi, kali/menit & $120(90-192)^{*}$ \\
Frekuensi pernapasan, kali/menit & $32(20-80)^{*}$ \\
Hemoglobin, g/dL & $10,9 \mathrm{~g} / \mathrm{dL}(2,6-16,8)^{*}$ \\
Leukosit, $/ \mu \mathrm{l}$ & $12.200(3.700-26.400)^{*}$ \\
Trombosit, $/ \mu \mathrm{l}$ & $315.832( \pm 147.103,8) \#$ \\
Absolute neutrophil count, / $\mathrm{ll}$ & $6250(1.230-20.592)^{*}$ \\
Prokalsitonin, ng/ml & $3,4(0,04-71,9)$ \\
Infeksi serius & $4,98(0,04-71,9)$ \\
Infeksi tidak serius & $0,6(0,5-0,8)$ \\
CRP, ng/ml & $1,95(0-15,5)$ \\
Infeksi serius & $1,2(0-12)$ \\
Infeksi tidak serius & $2,9(0-15,5)$ \\
\hline
\end{tabular}

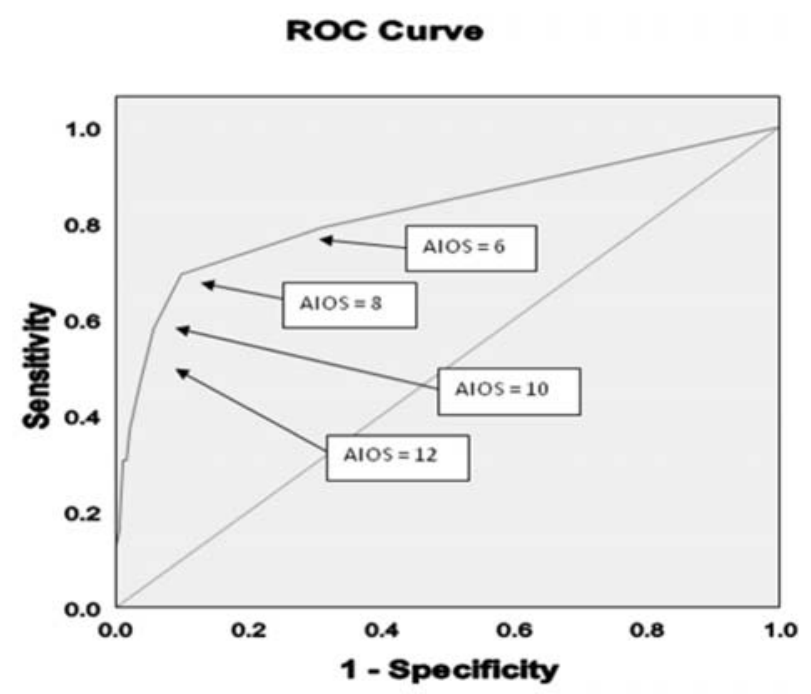

Gambar 1. Kurva ROC AIOS untuk memprediksi infeksi bakterial serius

Catatan: area di bawah kurva $=0,824$ 
A.A.A. Putu Indah Pratiwi dkk: Penggunaan acute illness observation scale (AIOS) sebagai prediktor infeksi serius pada anak 3-36 bulan dengan demam

Semua subjek yang menjalani pemeriksaan radiologis dada menunjukkan gambaran abnormal berupa infiltrat (22 subjek). Hasil biakan darah ditemukan positif pada 7 dari 27 subjek yang dilakukan pemeriksaan biakan darah. Hasil biakan urin positif pada 10 dari 18 subjek, biakan tinja 2 dari 4 subjek, dan biakan sputum ETT positif pada 2 dari 3 subjek. Tidak ditemukan kuman penyebab dominan dari hasil biakan.

Diagnosis yang paling sering ditegakkan adalah sindrom virus yang ditemukan pada 132 subjek $(51,5 \%)$. Infeksi serius ditemukan pada 62 subjek $(24,2 \%)$. Diagnosis infeksi serius tersering adalah pneumonia pada 22 subjek (35,5\%). Sebagian besar infeksi serius ditemukan pada kelompok usia 3-12 bulan (39 subjek,[62,8\%]).

Median skor AIOS adalah 6 (6-30), sebagian besar subjek $(81,6 \%)$ mendapat skor AIOS $\leq 10$, sementara sisanya, 47 subjek $(12,4 \%)$ mendapat skor AIOS $>10$. Terdapat perbedaan skor AIOS yang bermakna antara infeksi bakterial serius dan tidak serius. Median skor AIOS pada infeksi bakterial serius adalah 12 (6-30) dan pada infeksi tidak serius adalah 6 (6-24).

Sensitivitas skor AIOS $>10$ untuk mendiagnosis infeksi serius pada anak 3-36 bulan pada penelitian ini adalah $58,06 \%$, spesifisitas $94,33 \%$, nilai duga positif $76,6 \%$, nilai duga negatif $87,56 \%$, rasio kemungkinan positif 10,24, dan rasio kemungkinan negatif 0,43. Data skor AIOS kemudian dimasukkan ke dalam kurva receiver operating characteristic (Gambar 1) untuk mencari nilai titik potong AIOS optimal dan kemudian dicari nilai diagnostik titik potong $6,8,10$, dan 12 (Tabel 3).
Pada Tabel 3 tampak bahwa skor yang memberikan nilai sensitivitas, spesifisitas, nilai duga positif, nilai duga negatif, rasio kemungkinan positif, dan rasio kemungkinan negatif adalah skor AIOS 8. Skor 8 dianggap sebagai titik potong yang paling baik untuk memprediksi infeksi bakterial serius pada anak 3-36 bulan.

\section{Pembahasan}

Penelitian multisenter pertama di Indonesia untuk menguji nilai diagnostik AIOS dalam memprediksi infeksi bakterial serius pada anak usia 3-36 bulan dengan demam. Infeksi bakterial serius pada anak 3-36 bulan kadang kala sulit dibedakan dengan infeksi ringan. Prevalensi infeksi bakterial serius pada 3-36 bulan tinggi, yaitu 5-16\% mendorong klinisi untuk cenderung melakukan diagnosis dan tata laksana demam yang tidak tepat. Isu resistensi antibiotik dan timbulnya kuman super mendorong kesadaran perlunya suatu alat diagnostik yang baik untuk membantu membedakan infeksi bakterial serius dengan infeksi ringan pada kelompok usia 3-36 bulan. Tujuan utama penelitian untuk mendorong tata laksana demam yang rasional walaupun harus disadari bahwa sampai saat ini belum dapat ditegakkan diagnosis penyebab demam dengan hanya menggunakan satu alat uji. Seni ilmu kedokteran yang meramu observasi, anamnesis, pemeriksaan fisis, dan memilih pemeriksaan penunjang perlu dilakukan seorang klinisi untuk menegakkan diagnosis penyebab demam.

Tabel 3. Nilai diagnostik AIOS untuk memprediksi infeksi serius pada beberapa titik potong

\begin{tabular}{lcccc}
\hline & \multicolumn{3}{c}{ Titik potong AIOS untuk memprediksi infeksi serius } \\
\cline { 2 - 5 } & $>6$ positif & $>8$ positif & $>10$ positif & $>12$ positif \\
\hline Positif & 49 & 43 & 36 & 29 \\
Positif palsu & 60 & 19 & 11 & 7 \\
Negatif & 134 & 175 & 183 & 187 \\
Negatif palsu & 13 & 19 & 26 & 33 \\
Total & 256 & 256 & 256 & 256 \\
Sensitivitas (\%) & 79,03 & 69,35 & 58,06 & 46,77 \\
Spesifisitas (\%) & 69,07 & 90,2 & 94,33 & 96,39 \\
Nilai duga positif (\%) & 44,95 & 69,35 & 76,6 & 80,55 \\
Nilai duga negatif (\%) & 91,15 & 90,2 & 87,56 & 85 \\
Rasio kemungkinan positif & 2,55 & 7,08 & 10,24 & 12,96 \\
Rasio kemungkinan negatif & 0,3 & 0,34 & 0,44 & 0,55 \\
\hline
\end{tabular}


A.A.A. Putu Indah Pratiwi dkk: Penggunaan acute illness observation scale (AIOS) sebagai prediktor infeksi serius pada anak 3-36 bulan dengan demam

Penelitian kami menunjukkan AIOS adalah instrumen yang cukup baik untuk memprediksi infeksi bakterial serius pada anak 3-36 bulan dengan demam. Spesifisitas yang tinggi menyebabkan subjek dengan skor AIOS positif sangat mungkin mengalami infeksi bakterial serius dan nilai duga negatif yang tinggi menunjukkan bahwa skala ini baik digunakan untuk menyingkirkan infeksi bakterial serius pada anak 3-36 bulan. Skala AIOS juga memiliki nilai rasio kemungkinan positif yang tinggi dengan kemungkinan subjek yang sakit memberikan hasil skor yang positif 10,24 kali lipat bila dibandingkan dengan subjek sehat memberikan hasil skor positif. Sensitivitas skala AIOS yang rendah pada penelitian ini menyebabkan hasil negatif harus diterjemahkan dengan hati-hati karena besar kemungkinan terjadi negatif palsu.

Pada penelitian terdahulu, AIOS memberikan nilai diagnostik yang berbeda-beda. Nilai sensitivitas AIOS bervariasi dari 5,2\%-87,9\% sementara spesifisitas antara 73\%-96,7\%. Perbandingan skor AIOS ini tertera pada Tabel 4.

Sebagian besar penelitian, dilakukan pada pasien rawat jalan dengan prevalensi bakteremia tersembunyi yang lebih kecil dari pasien rawat inap. Hal itu berdampak pada rendahnya sensitivitas pada laporan penelitian tersebut seperti pada penelitian kami. Sensitivitas yang lebih tinggi ditemukan pada penelitian yang dilakukan oleh Bang $\mathrm{dkk}^{7} \mathrm{di}$ India yang melakukan penelitian pada pasien rawat inap dengan prevalensi bakteremia jauh lebih tinggi dari penelitian sebelumnya. Nilai duga negatif AIOS pada semua penelitian termasuk pada penelitian kami menunjukkan nilai yang tinggi sehingga dapat dikatakan skala ini sangat baik digunakan untuk menyingkirkan infeksi bakterial serius. Ditemukan area di bawah AIOS adalah 0,824 yang menunjukkan bahwa AIOS merupakan instrumen yang baik untuk mendiagnosis infeksi bakterial serius. Sebagai alat uji tapis, harus dicari nilai titik potong yang memiliki nilai sensitivitas dan spesifisitas kira-kira sama baik. Pada penelitian kami, syarat tersebut terpenuhi pada titik potong skor AIOS $>8$. Pada titik potong 8 instrumen AIOS memiliki sensitivitas $69,35 \%$, spesifisitas $90,2 \%$, nilai duga positif $69,35 \%$, nilai duga negatif $90,2 \%$, rasio kemungkinan positif 7,08 , dan rasio kemungkinan negatif 0,34 .

Perbedaan nilai titik potong karena cara pengambilan subjek dengan cara convenient sampling. Kriteria inklusi demam yaitu suhu $\geq 37,5^{\circ} \mathrm{C}$ yang lebih rendah bila dibandingkan penelitian lain sebelumnya dipikirkan juga berpengaruh mengingat dari penelitian sebelumnya tampak bahwa sensitivitas AIOS menurun saat demam turun. ${ }^{11}$ Titik potong suhu $\geq 37,5^{\circ} \mathrm{C}$ dengan pemeriksaan suhu di aksila dipilih karena dari penelitian pendahuluan ditemukan bahwa sekitar $60 \%$ subjek yang dibawa berobat tidak diperiksa suhunya di rumah dan saat datang berobat sebagian subjek baru mendapat antipiretik sehingga demam

Tabel 4. Berbagai penelitian AIOS

\begin{tabular}{|c|c|c|c|c|c|c|c|c|}
\hline $\begin{array}{c}\text { Pengarang } \\
\text { (tahun) }\end{array}$ & $\begin{array}{l}\text { Jumlah } \\
\text { (n) }\end{array}$ & Populasi & Hasil & $\begin{array}{l}\text { Sens } \\
(\%)\end{array}$ & $\begin{array}{l}\text { Spes } \\
(\%)\end{array}$ & $\begin{array}{l}\text { PPV } \\
(\%)\end{array}$ & $\begin{array}{l}\text { NPV } \\
(\%)\end{array}$ & Keterangan \\
\hline $\begin{array}{l}\text { McCarthy } \\
\text { (1982) }\end{array}$ & 165 & $\begin{array}{l}\text { Poliklin ik dan UGD, } \\
\leq 24 \text { bulan, } \geq 38,3^{\circ} \mathrm{C}\end{array}$ & $\begin{array}{l}\text { Infeksi serius } \\
\mathrm{n}=26(15,8 \%)\end{array}$ & 77 & 88 & 56 & 97,3 & $\begin{array}{l}\text { Kappa }= \\
0,47-0,73\end{array}$ \\
\hline $\begin{array}{l}\text { Baker MD } \\
\text { dkk. }^{10} \\
(1990)\end{array}$ & 126 & $\begin{array}{l}\text { UGD, 29-56 hari, } \\
\geq 38,2^{\circ} \mathrm{C}\end{array}$ & $\begin{array}{l}\text { Infeksi bakteri } \\
(9,5 \%)\end{array}$ & 33 & 73 & 11 & 91 & $\begin{array}{l}\text { Tidak bisa } \\
\text { digunakan } \\
<2 \text { bulan }\end{array}$ \\
\hline $\begin{array}{l}\text { Baker RC } \\
\text { dkk. }^{11} \\
(1989)\end{array}$ & 154 & $\begin{array}{l}\text { Poliklinik dan UGD, } \\
3-24 \text { bulan, } \geq 39,4^{\circ} \mathrm{C}\end{array}$ & $\begin{array}{l}\text { Bakteremia } \\
\mathrm{n}=19(12,3 \%)\end{array}$ & 68 & 77 & 30 & & $\begin{array}{l}\text { Convenient } \\
\text { sampling }\end{array}$ \\
\hline $\begin{array}{l}\text { Teach } \\
\text { dkk. }^{12} \\
(1995)\end{array}$ & 6611 & $\begin{array}{l}\text { Poliklinik, } 90 \text { hari- } 36 \text { bulan, } \\
\geq 39^{\circ} \mathrm{C}\end{array}$ & $\begin{array}{l}\text { Bakteremia } \\
\text { tersembunyi } \\
\mathrm{n}=192(2,9 \%)\end{array}$ & 5,2 & 96,7 & 4,5 & 97,1 & $\begin{array}{l}\text { Pasien dengan } \\
\text { klinis baik }\end{array}$ \\
\hline $\begin{array}{l}\text { Bang dkk. } \\
(2009)\end{array}$ & 219 & $\begin{array}{l}\text { Rawat inap, } 3-36 \text { bulan, } \\
\geq 38^{\circ} \mathrm{C}\end{array}$ & $\begin{array}{l}\text { Bakteremia } \\
28,16 \%\end{array}$ & 87,9 & 83,8 & 68 & 94,7 & $\begin{array}{l}\text { Consecutive } \\
\text { sampling }\end{array}$ \\
\hline $\begin{array}{l}\text { Penelitian } \\
\text { Pratiwi IP dkk } \\
\text { (2010) }\end{array}$ & 256 & $\begin{array}{l}\text { Rawat jalan dan inap, } \\
3-36 \text { bln, } \geq 37,5^{\circ} \mathrm{C}\end{array}$ & $\begin{array}{l}\text { Bakteremia } \\
24,2 \%\end{array}$ & 58,06 & 94,33 & 76,6 & 87,56 & $\begin{array}{l}\text { Convenient } \\
\text { sampling }\end{array}$ \\
\hline
\end{tabular}

Sari Pediatri, Vol. 12, No. 2, Agustus 2010 
A.A.A. Putu Indah Pratiwi dkk: Penggunaan acute illness observation scale (AIOS) sebagai prediktor infeksi serius pada anak 3-36 bulan dengan demam

tidak terdokumentasi dengan baik. Kendala tersebut diatasi dengan memberikan edukasi pada orangtua/ pengasuh untuk mengukur suhu dalam 24 jam sesudah berobat ke dokter sebelum meminum obat antipiretik. Pengukuran suhu per aksila paling mudah dan nyaman dilakukan di rumah.

Kemungkinan lain dari perbedaan nilai titik potong ROC adalah tidak dibedakan subjek yang mendapat antipiretik atau tidak. Diasumsikan pasien yang sudah mendapat antipiretik merasa lebih nyaman sehingga skor AIOS turun namun bahkan dari penelitian sebelumnya asumsi ini tidak terbukti. ${ }^{13}$

Bharti ${ }^{14}$ menyimpulkan bahwa AIOS dapat membantu dokter dan tenaga medis untuk mendiagnosis derajat berat penyakit pada pasien saat digunakan bersama MTBS. Melalui skrining AIOS juga dapat membuat tenaga kesehatan lebih bijak memberikan pengobatan pasien mengingat dalam penelitian kami ditemukan pasien pneumonia dengan skor AIOS yang $<10$ dan penggunaan antibiotik kloramfenikol oral masih efektif. Skala AIOS juga sangat berguna bila digunakan oleh orangtua, dapat meningkatkan pengetahuan orangtua untuk mengidentifikasi derajat berat sakit seorang anak sejak dari rumah, sejalan dengan penelitian yang dilakukan oleh McCarthy dkk pada tahun 1991. Penggunaan skala AIOS oleh orangtua tentu memerlukan penelitian tersendiri, terutama dengan memperhatikan tingkat pendidikan orangtua/pengasuh. Penggunaan AIOS oleh orangtua/pengasuh memerlukan pengenalan dan edukasi kepada orangtua/pengasuh. ${ }^{15}$ Penelitian McCarthy dkk dilakukan pada kelompok masyarakat dengan tingkat pendidikan dan ekonomi menengah. Jenis subjek penelitian diasumsikan serupa dengan mayoritas pasien di Indonesia sehingga diharapkan strategi yang sama dapat digunakan di Indonesia.

Skala AIOS dapat digunakan untuk mengarahkan observasi dokter untuk membuat hipotesis awal yang terarah. Rangkaian diagnosis selanjutnya akan merupakan tahapan yang kompleks dan cermat meliputi anamnesis dan pemeriksaan fisis untuk selanjutnya menentukan diagnosis dan tata laksana pasien.

Keterbatasan penelitian kami adalah jumlah pasien penelitian kurang dari perhitungan subyek minimal, dengan angka drop out 5,9\% (5-10\%) diharapkan subjek yang dianalisis dapat mewakili jumlah pasien yang awalnya hendak diteliti. Prevalensi yang didapat pada subjek penelitian ini tidak dapat digunakan untuk mewakili populasi umum karena metode pemilihan sampel dengan convenient sampling. Bias antara tiga pengamat diatasi dengan melakukan uji coba pengukuran skala sebelum penelitian dimulai dan menghitung kesesuaian interobserver pada 10 sampel. Hasil kesesuaian interobserver pada penelitian ini sangat baik, yaitu 1,0 sehingga bias pengamat dalam penelitian ini diharapkan dapat diatasi.

Baku emas diagnosis infeksi serius, yang salah satunya ditegakkan berdasarkan diagnosis. Tidak adanya satu peneliti khusus untuk menegakkan diagnosis subjek dapat menimbulkan bias penelitian, diatasi dengan hanya memilih diagnosis subjek ditegakkan oleh dokter anak di rumah sakit tersebut. Diagnosis juga ditegakkan berdasarkan standar pelayanan kesehatan anak yang dibuat oleh Ikatan Dokter Anak Indonesia sehingga diharapkan semua diagnosis memiliki standar yang sama.

Penelitian yang dilakukan McCarthy ${ }^{5}$ dan $\mathrm{Bang}^{7}$ terlihat bahwa AIOS memiliki keandalan yang cukup baik dengan nilai Kappa masing-masing 0,47-0,73 dan 0,79. Nilai Kappa penelitian 1,00 dilakukan pada 10 subyek, data tersebut sulit dinilai kemaknaannya. Namun dengan melihat hasil penelitian sebelumnya dan pengalaman pada penelitian kami, diharapkan AIOS dapat digunakan oleh tenaga medis untuk menyingkirkan kemungkinan infeksi serius sehingga tata laksana demam pada anak 3-36 bulan dapat lebih rasional.

Sebagai simpulan, AIOS adalah instrumen yang baik untuk memprediksi infeksi bakterial serius pada anak 3-36 bulan. Penggunaan AIOS dapat mengarahkan penegakan hipotesis awal yang baik namun penggunaannya harus digabungkan dengan anamnesis dan pemeriksaan fisis yang baik. Ditemukan nilai titik potong $>8$, namun penggunaan skor ini masih memerlukan penelitian lebih lanjut mengingat terdapat beberapa keterbatasan dalam penelitian ini yang bisa menjadi perancu.

\section{Daftar pustaka}

1. Goldman RD, Scolnik D, Chauvin-Kimoff L, Farion KJ, Ali S, Lynch T. Practice variations in the treatment of febrile infants among pediatric emergency physicians. Pediatrics. 2009; 124:439-45.

2. Powell KR. Fever without a focus. Dalam: Kliegman RM, Behrman RE, Jenson HB, Stanton BF, penyunting. Nelson textbook of pediatrics. Edisi ke-ke 18 . Philadelphia: Saunders; 2007.h.1087-93. 
A.A.A. Putu Indah Pratiwi dkk: Penggunaan acute illness observation scale (AIOS) sebagai prediktor infeksi serius pada anak 3-36 bulan dengan demam

3. McCarthy PL, Jekel JF, Stashwick CA, Spiesel SZ, Dolan TF, Sharpe MR. Further definition of history and observation variables in assessing febrile children. Pediatrics. 1981;67:687-93.

4. Singhi S, Chaudhuri M. Functional and behavioral responses as marker of illness, and outcome in infants under 2 months. Indian Pediatr. 1995;32:763-71.

5. McCarthy PL, Sharpe MR, Spiesel SZ, Dolan TF, Forsyth BW, DeWitt TG dkk. Observation scales to identify serious illness febrile children. Pediatrics. 1982;70:802-9.

6. McCarthy PL, Cicchetti DV, Sznajderman SD, Forsyth BC, Baron MA, Fink HD. Demographic, clinical, and psychosocial predictors of reliability of mothers' clinical judgments. Pediatrics. 1991;88:1041-6.

7. Bang A, Chaturvedi P. Yale observation scale for prediction bacteremia in febrile children. Indian J Pediatr. 2009;76:599-604.

8. Lee GM, Fleisher GR, Harper MB. Management of febrile children in the age of the conjugate pneumococcal vaccine: A cost-effectiveness analysis. Pediatrics. 2001;108:835-44.

9. Idris NS, Soedibyo S. Penggunaan acute illness observation
(AIOS) untuk memprediksi penyakit serius pada anak demam. Majalah Kedokteran Indonesia. 2010.

10. Baker MD, Avner JR, Bell LM. Failure of infant observation scales in detecting serious illness in febrile, 4-8 week-old infant. Pediatrics. 1990;85:1040-3.

11. Baker RC, Tiller T, Bausher JC, Bellet PS, Finley $\mathrm{AH}$, Lenane AM dkk. Severity of disease correlated with fever reduction in febrile infants. Pediatrics. 1989;83:1016-9.

12. Teach SJ, Fleisher GR. Efficacy of an observation scale in detecting bacteremia in febrile children three to thirty-six months of age, treated as outpatients. J Pediatr. 1994;126:877-81.

13. Mackowiak PA. Diagnostic implications and clinical consequences of antipyretic therapy. Clin Infect Dis. 2000;31:230-3.

14. Bharti B, Bharti S, Verma V. Role of acute illness observation scale (AIOS) in managing severe childhood pneumonia. Indian J Pediatr. 2007;74:27-32.

15. McCarthy PL, Sznajderan SD, Lustman Findling K, Baron MA, Fink HD, Czarkowski N dkk. Mother's clinical judgment: a randomized trial of the Acute Illness Observation Scales. J Pediatr. 1990;116:200-6. 